\title{
Research on Translation Model Analysis Based on the Acceptance Theory
}

\author{
Hua Wei \\ Department of Foreign Languages, Xingtai University, XingTai, China \\ w_ei_hua@126.com
}

\begin{abstract}
Keywords: acceptance theory; mathematical physics equation; translation model; observation data; $\alpha$-coefficient test
\end{abstract}

\begin{abstract}
In the current international background, Business English is used more and more widely, but how to achieve optimal configuration of resources and efficient business English teaching in colleges and universities, and how to make college students turn from passive accepting to active learning are essential for the community to be concerned about. Based on the Acceptance Theory, this paper analyzes the present situation of the teaching job in Business English translation and the establishment of the Business English translation model in order to offer some guidance for business English teaching in Chinese universities. Meanwile, this model will also enable students to be more active and more initiative in business English class, help to improve their skill in English translation, and develop their ability in both learning and thinking. By doing so, the goal of individual integrated development will be achieved.
\end{abstract}

\section{Introduction}

In the context of the times, the whole country's emphasis on English learning and the importance of English are growing. The society needs not only speaking English, but needs more comprehensive business knowledge and proficient complex applications of the current talents[1]. Many colleges and universities offer business English as the major course and they also provide some other additional compulsory and elective courses related to Business English translation[2]. Moreover, Business English translation is also one of the main tasks the students will take up after their graduation. Therefore, it is essential that colleges should integrate theory with practice when carrying out Business English teaching in the translation course. With regard to tertiary education, special attention should be paid to the English education[3]. Based on the Theory of Acception, this paper analyzes the present situation of the teaching job in Business English translation and the establishment of the Business English translation model in order to offer some guidance for business English teaching in Chinese universities and enable students to be more active and more initiative in business English class[4,5]. Teaching business English translation from the theory perspective also helps to change the mode of teaching and to enhance students' interest in learning and improve the quality of teaching of English business translation, which has certain practical significance in guiding universities to better carry out the education of the English business translation.

\section{The Literature theory and method}

Acceptance theory is a new research method in the current English translation academic study[6]. One of the objects of English translation is the readers, and it is reader-centered and reader is also the purpose, which will bring quite a significant change for the academic research methods of the English translation theory and even the history of English translation. The acceptance theory is from Constance, Germany, the school of academic research, and it is mainly determined that readers are the acceptance theory's active targets. Acceptance theory's most fundamental characteristic is to analyze acceptance. Then since they need to accept translation, naturally the readers need to be able to read the English translations and can understand them.[7]. The relationship between readers and translating and writing are the acceptance theory emphasizes. For the translation of the text, its meaning is not clear, and it is non-independent and non-absolute text and translation of the text; its significance lies in the acceptance theory of the contemporary reader during specific reading in order to produce a specific meaning.

Acceptance Theory changes such traditional mechanical forms as simple syntax or statement translation and adds a consideration for the readers' acceptance, which is a new model and concept. Thus, during the process of business English translation, we should no longer simply have the pursuit 
of the correct syntax, statements and others, more important for us is to grasp the mood and meaning of the works, which is the same for everyone in improving business English education, and it will also drive the innovation of business English translation teaching. So the article is based on the theory perspective and a more comprehensive study, which not only helps evaluate business English translation teaching effect, but better guide universities to innovate and find a more appropriate and effective way for the comprehensive development of teaching and teaching of business English translation.

This paper uses questionnaires in the survey, first to understand the status quo of universities and enterprises to develop business English translation; and the second is to understand the effectiveness of teaching business English translation acceptance theory. The research method is based on a statistical evaluation method, which is[8]:

$\begin{array}{ccccccc}\text { Sample } & V & a & l & u & e & \bar{y} \\ 1 & y_{11} & y_{12} & \cdot & y_{1 n} & \cdot & \overline{y_{1}} \\ 2 & y_{21} & y_{22} & \cdot & y_{2 n} & \cdot & \overline{y_{2}} \\ \cdot & \cdot & \cdot & \cdot & \cdot & \cdot & \cdot \\ \cdot & \cdot & \cdot & \cdot & \cdot & \cdot & \cdot \\ \cdot & \cdot & \cdot & \cdot & \cdot & \cdot & \cdot \\ k & k_{k 1} & k_{k 2} & \cdot & k_{k n} & \cdot & \overline{y_{k}}\end{array}$

For the tested original data, we need to carry out the following analysis[9]:

$$
y_{j i}=\left(\begin{array}{l}
y_{j i 1} \\
y_{j i 2} \\
\ldots \\
y_{j i q}
\end{array}\right)=\mu+\tau_{j}+f_{j i} \quad\left\{\begin{array}{l}
j=1,2, \ldots, k \\
i=1,2, \ldots, m
\end{array}\right.
$$

And it can also be based on the above-mentioned formulas to make decomposition[10]:

$$
\mathrm{y}_{\mathrm{ji}}=\overline{\mathrm{y}}+\left(\overline{\mathrm{y}}_{j}-\overline{\mathrm{y}}\right)+\mathrm{y}_{\mathrm{ji}}-y_{j}
$$

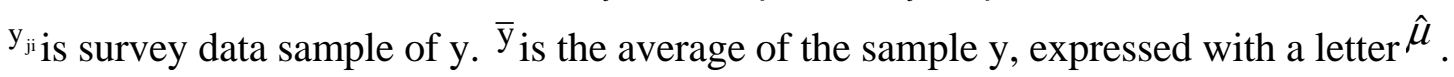

$\bar{y}_{j}-\bar{y}_{\text {is }}$ the corresponding effect valuation after data processing, expressed with a letter $\hat{\tau}_{i}$.

$\mathrm{y}_{\mathrm{ji}}-y_{j}$ is the residual value of the statistics, expressed with a letter $\hat{e}_{i j}$.

In the design of the questionnaire, we examine the design of the questionnaire from the two aspects: reliability and validity. The reliability expression formula is[11]:

$$
R_{x x}=\frac{S T 2}{S_{x}^{2}}
$$

Representation of the true variance is ST2, and we actually get variance Sx2. Through input raw data with statistical software analysis we can get that.

After inspection of internal consistency, we are using alpha coefficient test[12]:

$$
\alpha=\left(\frac{k}{k-1}\right)\left(1-\frac{\sum S i 2}{S x 2}\right)
$$

Total representation of questionnaire items is $\mathrm{K}$, and a representation of an item value of the variance is $\mathrm{Si} 2$, and a representation of the variance of the values of all the items is Sx2.

\section{Business English Translation Model Based on the Acceptance Theory}

In the current Business English era, many colleges and universities have launched business English, additional business English translation compulsory and elective courses. Business English translation and will be involved in businesses. Business English translation is the professional that students after graduation will participate in and it is very important work. So it requires colleges and universities in the education can conduct business English translation courses to be close with the actual combination of college education and to strengthen the teaching of business English translation. And enterprises should strengthen the application of business English translation. The article researches on the college students, employees, and corporate research, in order to understand the current application status of business English translation, see Table 1. From business English translation status quo, we can find an appropriate and effective way to improve teaching methods. Business English translation is mainly used in academic research, technology, or product 
descriptions, special reports, meeting minutes, contracts and letters or e-mails for the subjects of the investigation.

\begin{tabular}{|c|c|c|c|c|c|c|}
\hline Object & $\begin{array}{l}\text { Academic } \\
\text { researches }\end{array}$ & $\begin{array}{c}\text { Technology or } \\
\text { product descriptions }\end{array}$ & $\begin{array}{l}\text { Special } \\
\text { reports }\end{array}$ & $\begin{array}{l}\text { Minutes } \\
\text { of the } \\
\text { meeting }\end{array}$ & Contract & $\begin{array}{c}\text { Letter } \\
\text { Or } \\
\text { e-mail } \\
\end{array}$ \\
\hline $\begin{array}{c}\text { College } \\
\text { students }\end{array}$ & $48.37 \%$ & $70.02 \%$ & $28.78 \%$ & $41.16 \%$ & $39.1 \%$ & $34.97 \%$ \\
\hline Employees & $5.14 \%$ & $42.64 \%$ & $2.02 \%$ & $2.02 \%$ & $16.68 \%$ & $29.1 \%$ \\
\hline Enterprises & $15 \%$ & $43 \%$ & $3 \%$ & 0 & $39 \%$ & $43 \%$ \\
\hline
\end{tabular}

It is shown in Table 1 and Figure 1 that for different objects, business English translation applications are not the same. For college students, the most important is a description of the technology or product, accounting for $70.02 \%$; the second is to carry out research on students, accounting for $48.37 \%$; ranking third is meeting minutes, accounting for $41.16 \%$, while the row at the end of the special reports are also accounted for more than $28 \%$. For employees, only a larger proportion of the application of the technology or product description, and a letter or e-mail, the contract, and the rest at about 5\%. For businesses, the deal with minutes of the meeting does not involve the rest and it will be involved in the application, but not accounted academic research, only $15 \%$, the same as the proportion of these two aspects of the technology or product descriptions, as well as a letter or e-mail , 43\%, followed by applications accounted for 39\% of the contract. For university students, employees and enterprises, these three types of objects in the application of technology or product described dominant, followed by a letter or e-mail, and then after that the application of the contract, as opposed to academic research, special reports and conference minutes of the application are mostly for college students. Enterprise and employees are in favor of the application and the actual exchange of actual business English.

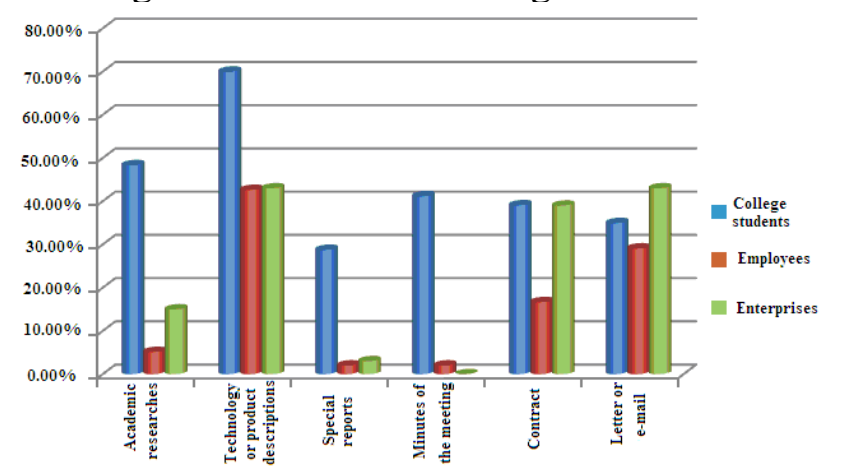

Figure 1. Comparison chart of business English translation application status data

From the acceptance theory perspective, the business English translation model is based on the acceptance of the translated works from readers, which can be expressed in three aspects, cognitive value of business English works read by the readers; rose for the inspection of the translated works; finally, establishing the standard English translation progressive mode, as is shown in Figure 2. Business English translation works have acceptable reading value. Business English translation accepts inspection. Business English translation has acceptance standard. The three parts proceed gradually and we can establish acceptable standards explicitly, then in turn act on the acceptance value of reading, in order to continuously improve the quality and the level of business English translation. For the accepted value of reading, business English translation is actually a special act of reading. Business English translation can reflect own ideas and combine to translate their own understanding, meaning and semantics. So the presentation is very different, which is closely linked with the living or working conditions of the readers.

Accepted testing method is affected by advertising quality of translation and is directly related to sales activities, so for the translation of the ad, it is very important work and is also particularly noteworthy. If an advertisement is translated very well and leaves deep impression on people, then it will bring people to accept this ad and will direct role to the direct effect.

With the continued progress and development of society, we have established explicitly accepted standards. People in the translation industry also begin to focus on certain standards with an expectation of achieving the standard formulation of business translation and in order to be able to provide effective guidance to the English translation in business activities according to the facts. Business English translation standard is closely related to the business of translation activities by these translation activities related factors, for business English translation not only need to have the appropriate knowledge of business English and International business English professional basis; 
what we need more is a Trinity business English knowledge structure able to meet the status quo and able to achieve professional business English translation.

\section{Conclusion}

Traditional education will not only make the students' education passive, but also does not match the fact in the era of convergence. Acceptance Theory considers the acceptance of the readers from a whole new perspective in order to evaluate the effectiveness of business English translation, which can help students to have more empathy, more fully strengthened education breakthroughs and improve and enrich teaching business English translation. Furthermore, it can guide colleges to actively carry out more effective business English translation education methods, so as to create a relaxing and good teaching atmosphere, making the students actively join the Business English translation classroom teaching; at the same time, we can make analysis of the nature of the reading of the translation work, and can accept the establishment of the standards. This not only helps to enhance the students to improve business English translation, but will also enhance the combination of the needs of enterprises. Acceptance Theory in business English translation teaching is effective, and we have to further strengthen and gradually improve the application of Acceptance Theory for business English translation teaching and explore more effective ways and means to enhance the students' abilities; meanwhile, we should ensure the orderly and efficient conduct of college business English translation teaching.

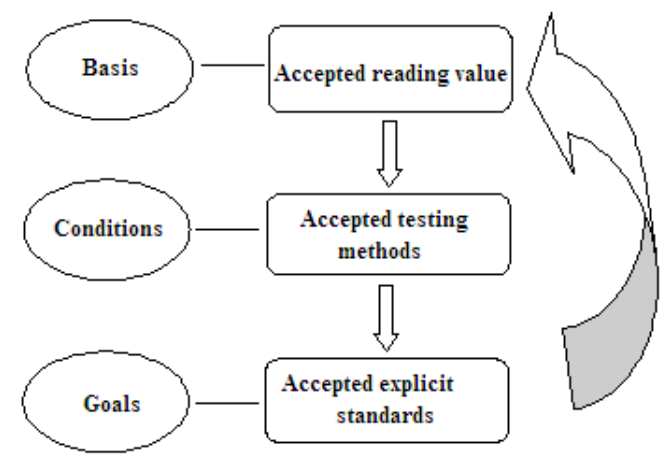

Figure 2. Business English translation model from acceptance perspective

\section{References}

[1] Li Jing, San You. Acceptance theory and Advertising Translation Standard [J]. Changsha Railway Institute (Social Sciences) ,2012( 04):37-41.

[2] Tong Yahui. Acceptance Revelation Theory in Translation Studies [J]. The Fujian Foreign Language,2012( 03);32-26.

[3] Liu Hu. Acceptance theory of literary translation diversified standard [J]. Jiangsu Radio \& Television University ,2010( 04):39-42.

[4] Wang Guifen. From the acceptance theory of the dominant position of the literary translation [J]. Jingzhou Normal University,2012 (03):104-106.

[5] Cao Shunfa. Advertising Translation [J]. Translation ,2012(01):67-69.

[6] Wu Huijian. Standards and conditions of translation - to Lin Yutang, My Country and My People "as an example [J]. Foreign Language Research , 2010(01):56-58.

[7] Sun Shengyong. Professional English translation knowledge structure Trinity says [J]. Foreign Language Research, 2010(01):31-33.

[8] Chen Dongcheng. On the readers' attention of the Advertising Slogan Translation [J]. Shenzhen University (Humanities and Social Sciences) ,2012 (06):12-14.

[9] Meng Lin, Zhan Jinghui. Pun in English ads use skills and translation [J]. Chinese translation ,2011 (05):81-84.

[10] Sun Shengyong. Acceptance theory in English translation of theoretical research model - based Business English Translation [J]. Chinese translation,2009 (10):91-94.

[11] Luo Yimin. Equivalent balance "internal syntax structure - to accept naturalization issues of aesthetic theory and Poetry Translation Shakespeare sonnets [J].South China Nornal University, 2011(3):56-59.

[12] Sun Shengyong. Business English translation of analytic philosophy research model [J]. Shanxi Finance and Economics University,2009(9):107-109. 